\title{
The Digitalization - Economic Growth Relationship in Developing Countries and the Role of Governance
}

\author{
Van Bon Nguyen*
}

\begin{abstract}
Digital technology is emerging as one of the suitable solutions to help developing economies catch up with advanced economies in the context of globalization. Progress in digital technology promotes economic growth in developing economies because it reduces transaction costs in economic activities and improves workers' skills and knowledge. Meanwhile, governance is the primary cause of economic growth. Therefore, this study raises a research question of whether governance significantly contributes to the digitalization - economic growth relationship in developing countries or not. For the answer, the study uses the difference GMM Arellano-Bond estimators to empirically examine the effects of digitalization, governance, and their interaction on economic growth for a group of 35 developing countries from 2006 to 2019. Then, the study applies the FE-IV estimator to check the robustness of estimates. The results indicate that digitalization and governance boost economic growth while their interaction hinders it. Furthermore, trade openness also increases economic growth. These findings suggest some crucial policy implications that governments in developing countries should establish appropriate conditions to promote digital technology so that citizens can peacefully express their views on government policies and regulations, which contributes to the economic development of the country.
\end{abstract}

Keywords: digitalization; governance; economic growth; developing countries; difference GMM Arellano-Bond estimator; FE-IV estimator.

JEL classification: E22; J24; O47.

\section{INTRODUCTION}

Poverty reduction in developing countries is one of the United Nations Millennium Development Goals (MDGs) (United Nations, 2000). The eight MDGs include: (1) Eradicating extreme poverty and hunger, (2) Achieve universal primary education, (3) Promoting gender equality and empower women, (4) Reducing child mortality, (5) Improving maternal health, (6) Combating HIV/AIDS, malaria, and other diseases, (7) Ensuring environmental sustainability, and (8) Developing a global partnership for development. To achieve this goal, a high economic growth rate and more jobs for people are a priority on the

"University of Finance - Marketing, Vietnam; e-mail: nv.bon@ufm.edu.vn. 
development agendas in these countries. In the context of rising globalization, the appropriate solutions in these countries are to promote digital technology development and improving institutional quality. Digital technology helps citizens access more easily knowledge and skills to improve their ability in seeking high-paying jobs and supports businesses in improving efficiency in management and production to increase competitiveness. Meanwhile, good institutional quality will increase the government's support for citizens and businesses, reduce transaction costs, improve the efficiency of economic activities, and thus promote economic growth. Notably, Hope (2009) notes that the lack of good institutional settings in most developing countries can lead to adverse impacts on the economic outcomes; thus, improving the institutional environment contributes significantly to the development agendas in these countries. More importantly, a good institutional environment will set up constructive governments with the capacity to implement development policies. Under a good institutional environment, governments establish appropriate conditions to promote and apply progress in digital technology that supports domestic economic activities and boosts economic growth. Despite the increasingly important role of digital technology, only a few related studies are carried out and most of these studies agree that digitalization plays a decisive role in transforming the economy into a digital economy with high competitiveness and efficiency. So far, in particular, no existing studies examine the role of governance in the digitalization economic growth relationship. Therefore, this study raises a research question as "Does governance significantly contribute to the digitalization-economic growth relationship in developing countries?"

Given the relevance of the topic, Vu (2011) develops an analytical framework to indicate three main channels by which digitalization positively affects economic growth. First, innovation and technology diffusion in a simple leader-follower model by Barro and Sala-iMartin (1995) can stimulate economic growth in both leader and follower economies. Second, efficiency of resources allocation is improved in a simple decision-making model by which digitalization increases the business performance of the average firm and, consequently, promotes economic growth. Third, digitalization decreases production costs, boosts demand and investment, and thus fosters output level and economic growth rate. Meanwhile, institutional quality/governance is the cause of economic growth in the long run (Acemoglu, Johnson, \& Robinson, 2005). Depending on institutional quality, progress in digital technology in a country can be accelerated or delayed. In countries with poor institutional settings, for instance, low democracy, the development of digital technology with the formation of social networks in which individuals can freely express their opinions can be a threat to the existence of government/state. Governments in these countries often formulate and implement regulations and laws (governance) to limit the development of social networks out of their control, implying that they put restrictions on the development of digital technology, leading to a decline in economic growth.

Stemming from the fact that both governance and digitalization play a crucial role in the process of economic development and growth in developing countries and governance can contribute significantly to the digitalization - economic growth relationship, the study empirically investigates the effects of digitalization, governance, and their interaction on economic growth for a group of 35 developing countries over the period 2006 - 2019 using the difference GMM Arellano-Bond estimators for estimation and the FE-IV estimator for robustness check. 
The next structure of the paper is shown in the following way. Section 2 is the literature review with a focus on the relationship between digitalization and economic growth. The characteristics and appropriateness of estimation methods are given in Section 3. Section 4 shows the empirical results and discussion while Section 5 concludes and suggests some crucial policy implications.

\section{LITERATURE REVIEW}

Digital technology plays a crucial role in the development agenda in most countries in the context of increasing globalization. Policymakers in developing economies look towards progress in digital technology as one of the appropriate solutions to promote economic growth and create more jobs. Except for Ishida (2015) and Bakari and Tiba (2020), all related studies confirm the positive role of digitalization on economic growth in the process of economic development.

Yousefi (2011) uses the pooled OLS estimator for a sample of 62 countries from 2000 to 2006 and finds that digitalization contributes significantly to economic growth in high and upper-middle-income countries, not in the lower-middle-income countries. Meanwhile, Qu, Simes, and O'Mahony (2017) show the positive effects of digitalization, trade openness and infrastructure on economic growth using the Pooled Mean Group (PMG) estimator for a group of 37 countries over the period 2000 - 2014. Similarly, Y. Li (2019) uses a dynamic panel data approach for 65 countries in the Belt and Road Region from 1996 to 2014 while Siddiqui and Singh (2019) use the co-integration technique for 15 major trading economies from 2001 to 2018. Y. Li (2019) suggests that countries need to apply various strategies to enhance actively the information industry development because the growth effects of digitalization strengthen along with the development of the Internet.

Notably, some recent related studies such as Chiemeke and Imafidor (2020), Habibi and Zabardast (2020), Myovella, Karacuka, and Haucap (2020), Nair, Pradhan, and Arvin (2020), Solomon and van Klyton (2020), Kurniawati (2021), and Usman, Ozturk, Hassan, Zafar, and Ullah (2021) highlight the indispensable role of digital technology in economic development in both developed and developing countries. Chiemeke and Imafidor (2020) employ the Structural Vector Autoregressive (SVAR) model for Nigeria between 1990 and 2019 while Habibi and Zabardast (2020) apply the OLS, fixed-effect, and one-step difference GMM Arellano-Bond estimators for 10 Middle Eastern and 24 OECD countries from 2000 to 2017. Habibi and Zabardast (2020) note the positive growth impact of digitalization for both groups of countries (developing and developed countries). In particular, trade openness and infrastructure promote economic growth, but inflation impedes it. In conclusion, they recommend governments in these countries invest more in digital technology to foster economic growth. Meanwhile, both Myovella et al. (2020) and Solomon and van Klyton (2020) respectively use the OLS, fixedeffect, and one-step system GMM Arellano-Bond estimators for groups of 41 Sub-Saharan African countries (SSA) and 33 the Organization for Economic Cooperation and Development economies (OECD) over the period 2006 - 2016 and for a group of 39 African countries from 2012 to 2016. Solomon and van Klyton (2020) also find the positive growth impact of digitalization for both groups of countries. Furthermore, trade openness and infrastructure enhance economic growth. In the same vein, Nair et al. (2020) note the positive growth impact of digitalization using the co-integration test, the fully modified ordinary least squares (FMOLS), and the dynamic ordinary least squares (DOLS) for 36 OECD economies over the 
period 1961 - 2018. They suggest that policymakers should take into account the role of digitalization in economic growth-enhancing initiatives. More recently, Kurniawati (2021) uses the panel co-integration test and the fully modified ordinary least squares (FMOLS) for a group of 25 Asian countries from 2000 to 2018 while Usman et al. (2021) use the bounds testing approach of co-integration and error correction modeling for four South Asian economies from 1990 to 2018. In particular, among related studies, only Albiman and Sulong (2016) introduce institutional quality into the empirical model as a control variable. Indeed, Albiman and Sulong (2016) use the one-step system GMM estimator for a sample of 45 Sub-Saharan African (SSA) countries between 1990 and 2014 and find the positive growth impact of digitalization. Besides, they note that institutional quality, trade openness, and infrastructure stimulate economic growth in these countries.

Unlike all the above-mentioned studies, Ishida (2015) applies the ARDL bounds testing approach for the dataset in Japan between 1980 and 2010 and notes that the impact of digitalization on economic growth in the short-run and long-run is not statistically significant. Meanwhile, Bakari and Tiba (2020) show the negative growth effect of digitalization using the ARDL bounds testing approach, panel ARDL model, fixed effect model, random effect model, FMOLS, 2SLS, RLS, GLM, and GMM estimators for four economies of the North Africa (Algeria, Egypt, Morocco, and Tunisia) from 1995 to 2017.

In short, from the literature perspective, no existing studies use the two-step GMM Arellano-Bond estimator. In comparison with existing related studies, therefore, this study highlights two aspects. First, it introduces governance into the digitalization - economic growth relationship. Second, it uses the two-step difference GMM Arellano-Bond estimator for estimation and the FE-IV estimator for robustness check.

\section{METHODOLOGY AND RESEARCH DATA}

\subsection{Methodology}

Following Myovella et al. (2020), the study suggests the empirical equation as follows:

$$
\begin{gathered}
G D P_{i t}=\lambda_{0}+\lambda_{1} G D P_{i t-1}+\lambda_{2} D I G_{i t}+\lambda_{3} G O V_{i t}+\lambda_{4}(D I G \times G O V)_{i t}+Z_{i t} \lambda^{\prime}+\mu_{i} \\
+\zeta_{i t} \text { (1) }
\end{gathered}
$$

where subscript $i$ and $t$ are the country and time index, respectively. GDP $P_{i t}$ is the GDP per capita - a proxy for economic growth, $G D P_{i t-I}$ is the initial level of economic growth, $D I G_{i t}$ is individuals using the Internet - a proxy for digitalization, $G O V_{i t}$ is governance (six dimensions of governance, including control of corruption, government effectiveness, political stability and absence of violence, regulatory quality, rule of law, voice and accountability), and $(D I G \times G O V)_{i t}$ is the interaction between digitalization and governance. $Z_{i t}$ is a set of control variables such as labor force, trade openness, inflation, and infrastructure; $\mu_{i}$ is an unobserved time-invariant, country-specific effect and $\zeta_{i t}$ is an observation-specific error term; $\lambda_{0}, \lambda_{1}, \lambda_{2}, \lambda_{3}, \lambda_{4}, \lambda_{5}$, and $\lambda$ ' are estimated coefficients. Following the related studies, control variables such as labor force, trade openness, inflation, and infrastructure are introduced into the empirical model. Y. Li (2019) and Kurniawati (2021) find out the positive impact of labor force on economic growth while Albiman and Sulong (2016), Qu et al. (2017), Y. Li (2019), Siddiqui and Singh (2019), Habibi and Zabardast (2020), and Kurniawati (2021) note that trade openness promotes it in host countries. In the same vein, Habibi and Zabardast 
(2020) report that an increase in inflation impedes economic growth, but Albiman and Sulong (2016), Qu et al. (2017), Siddiqui and Singh (2019), and Habibi and Zabardast (2020) show that infrastructure development improves it.

We apply Equation (1) to examine the effects of digitalization, governance, and their interaction on economic growth for a group of 35 developing countries. The study uses six dimensions of governance constructed by the World Bank to measure governance in which each dimension of governance has a value from -2.5 to 2.5 (Kaufmann, Kraay, \& Mastruzzi, 2011). However, there are four serious problems of econometrics from regressing Equation (1). Firstly, governance, labor force, and inflation may be endogenous. They may correlate with the term $\mu_{i}$, leading to the endogenous phenomenon. Secondly, some country-specific and unobserved time-invariant characteristics like anthropology and geography may correlate with regressors. They exist in the term $\mu_{i}$. Thirdly, the presence of $G D P_{i t-1}$ in the empirical equations may lead to a high autocorrelation. Fourthly, the panel dataset has a relatively large unit of countries $(\mathrm{N}=35)$ and a relatively short observation length $(\mathrm{T}=14)$. They can make the OLS estimator inconsistent and biased. FEM (fixed-effects model) and (REM) (randomeffects model) can not tackle autocorrelation and endogenous phenomena while the IV-2SLS (instrumental variable - two-stage least square) estimator requires some appropriate instrumental variables that are out of regressors in the model. Thus, as suggested by Judson and Owen (1999), the study applies the difference GMM Arellano-Bond estimators for estimation and the FE-IV estimator for robustness check.

The study will use the GMM (general method of moments) Arellano and Bond (1991) estimators first suggested by Holtz-Eakin, Newey, and Rosen (1988) for estimation. In Equation (1), the first difference will be taken to remove country-fixed effects. Next, the regressors in the first difference are used as instrumented by their lags based on the assumption that in the original empirical equations, time-varying white noises are not serially correlated (Judson \& Owen, 1999). This approach is the difference GMM estimator (D-GMM) that can handle simultaneity biases in regressions. The two-step D-GMM is more asymptotically efficient than the one-step D-GMM. Unfortunately, Roodman (2009) notes that the application of two-step D-GMM in small samples has some problems. They are set up by the proliferation of instruments, which quadratically rise as the time dimension increases. Thus, it makes the number of instruments larger than the number of countries. To eliminate it, Roodman (2009) suggests that studies apply the rule of thumb to ensure that the number of instruments is less than or equal to the number of countries.

Arellano-Bond statistic, Hansen statistic, and the Sargan statistic will test the validity of instruments in empirical equations. The Arellano-Bond test is applied to search for the autocorrelation of errors in the first difference. Therefore, the study ignores the first autocorrelation $\mathrm{AR}(1)$ and tests the second autocorrelation $\mathrm{AR}(2)$ on the first difference series of errors. Meanwhile, the null hypothesis for the Hansen and Sargan tests is $\mathrm{H}_{0}$ : the instrument is strictly exogenous, implying that it does not correlate with the errors. Meanwhile, Baum, Schaffer, and Stillman (2003) note that the FE-IV estimator is a kind of instrumental variable estimation for panel data with fixed effects in which some variables in the model may be endogenous. The Sargan test is applied to assess the validity of instruments by the FE-IV estimator. 


\subsection{Research data}

The variables are GDP per capita, individuals using the Internet, governance indicators, labor force, trade, inflation, and fixed telephone subscriptions (per 100 people). Data are taken from the World Bank World Development Indicators (WDI) and Worldwide Governance Indicators (WGI) database. Due to data of individuals using the Internet in several countries not being available, the research sample only consists of 35 countries $^{1}$ from 2006 to 2019. Based on the classification of the International Monetary Fund, these countries are developing ones.

The Annex describes the definition and descriptive statistics of the data (Table A). The results in Table B show that governance in the sample of 35 developing countries is relatively low. It is completely similar to that in the approach of S. Li and Filer (2007) that most developing economies are those with relation-based governance (poor governance). Table $\mathrm{C}$ indicates that digitalization, labor force, and infrastructure are positively associated with economic growth while trade openness and inflation are negatively linked with it. Meanwhile, Table D shows that the correlation coefficients between dimensions of governance are relatively high, so these dimensions are separately used in empirical equations to eliminate the co-linearity.

An official report from UNCTAD (2021) notes that there is a gap in global digital technology development across countries. Progress in digitalization indicates a large gap between hyperdigitized and less-connected economies. Only one in five uses the Internet in the least developed economies while it is four out of five in advanced economies. In particular, in some sectors such as frontier technology and digital data, the wide distance is more considerable. For instance, both Latin America and Africa occupy less than 5\% of the world's colocation data centers.

According to a report from ITU (2018), around 51.2\% of the global population (3.9 billion people online) used the Internet in 2018. Although the statistical data note progress in digital technology, there is still a big gap in terms of the Internet. Most of the growth in Internet access has come from developing countries, occupying around $90 \%$ of the global increase in which the highest growth rate belongs to the least developed economies. In recent years, however, the growth rate of Internet use has declined, suggesting that a rise in Internet access for citizens in many low- and middle-income economies is possible. The main reasons for the decline in the growth rate of new online people stem partly from their inability to connect to the basic Internet and related devices. Indeed, only $40 \%$ of people in low- and middle-income countries use the Internet. 2.3 billion people worldwide live in countries where $1 \mathrm{~GB}$ mobile broadband plans are unaffordable for middle-income people. In comparison with those in other developing regions, African people have to pay the highest average charge of Internet access.

Also, the report from UNCTAD (2021) shows that the digital economy does not reflect geographically a traditional North-South distance. Accordingly, the United States (advanced economy) and China (developing economy) are the most leaders. These two countries capture $75 \%$ of the world market for public cloud computation, $75 \%$ of all patents linked to the blockchain, and $50 \%$ of global spending on the Internet of things. They also occupy about $90 \%$ of the capitalization value of the 70 globally largest digital platforms while Europe and Africa and Latin America get 4\% and 1\%, respectively. Therefore, the rest of the world (especially Africa and Latin America) is following China and the United States in terms of progress in digital technology.

In short, in the context of increasing globalization and digitization, the disparity in digital technology development between developing and developed countries is one of the obstacles that makes developing countries hard to catch up with developed countries in terms of per 
capita income and level of development. The digital divide is hindering development in developing countries (UNCTAD, 2018). Notably, Frieden (2001) notes that income per capita of the average developed economy was seven times that of the average developing economy in 2000. Although income inequality between economies has improved in the last 20 years, the average income of people living in North America is 16 times higher than that of people in sub-Saharan Africa (United Nations, 2020). Reforming institutional settings in developing countries is one of the necessary solutions to promote the development of digital platforms, narrowing the digital technology gap between developed and developing countries. This process will help developing countries catch up with developed countries.

\section{ESTIMATED RESULTS AND DISCUSSION}

\subsection{The two-step D-GMM estimates}

The two-step D-GMM estimates are given in Table no. 1. The results in correspondence with each dimension of governance are shown in each column. In all estimation procedures, we discover that digitalization is endogenous, thus we use digitalization as instrumented in the GMM-style and the remaining variables (economic growth, governance, labor force, trade openness, inflation, and infrastructure) as instruments in the IV-style.

The results across all models note that digitalization and governance promote economic growth while their interaction impedes it. Furthermore, trade openness also stimulates economic growth. The positive role of digitalization in economic growth can be found in all related studies except Ishida (2015) as mentioned in the literature review. Progress in digital technology in developing countries brings a good chance for people to receive knowledge and skills and for domestic companies to apply advanced technology in production and management. People in these countries can find jobs with a high salary while domestic companies improve competitiveness, reduce transaction costs, and increase profit. Therefore, digitalization promotes economic growth. Improving governance implies that governments formulate and implement regulations and policies to make people and domestic companies interact easily in all transactions. As a result, people can maximize their benefits while domestic companies can decrease transaction costs and enhance profit, which leads to economic growth. This finding is indicated in Albiman and Sulong (2016).

Contrary to digitalization and governance, their interaction hinders economic growth. In practice, progress in digital technology significantly improves the effectiveness of governments (Dobrolyubova, Klochkova, \& Alexandrov, 2019). In particular, Ndubuisi, Otioma, and Tetteh (2021) show that the positive impact of digital technology on services sector employment enhances as institutional quality becomes better. In this study, however, most developing countries have poor governance and low levels of democracy. The development of digital technology leads to the formation of social platforms such as Facebook, Twitter, Instagram, etc through which people can freely express their opinions that can be a threat to the government/state. As a result, governments in these countries often formulate and implement regulations and policies to limit the overgrowth of digitalization, especially out of government control. The peaceful expression of people's views can help the government to overcome limitations and shortcomings in economic management and development, especially equal opportunities in accessing national resources, thus promoting economic growth and development. In this study, therefore, poor governance in the 
developing countries somewhat limits the development of digital technology, and thus hinders economic growth. This finding also indicates that governments in developing economies should reform and improve governance to receive better outcomes of economic development.

The economic opening policy is aimed at promoting economic activities between countries and stimulating cross-border investment activities. Increasing trade openness contributes to improving innovation, enhancing productivity, and thus promoting economic growth. Governments in developing economies should strongly open the economy to promote trade exchange with other economies. Joining world economic organizations is one of the solutions to enhance a country's trade liberalization, which receives economic benefits. Albiman and Sulong (2016), Qu et al. (2017), Siddiqui and Singh (2019), Habibi and Zabardast (2020), and Kurniawati (2021) support the positive effect of trade openness on economic growth.

Table no. 1 - Digitalization, governance, and economic growth:

two-step D-GMM estimates, 2006 - 2019

\begin{tabular}{lcccccc} 
Dependent variable: Economic growth & (GDP per capita) \\
\hline Variables & GOV1 & GOV2 & GOV3 & GOV4 & GOV5 & GOV6 \\
\hline Economic growth (-1) & $0.258^{* * *}$ & $0.214^{* * *}$ & $0.324^{* * *}$ & $0.291^{* * *}$ & $0.244^{* * *}$ & $0.354^{* * *}$ \\
& $(0.064)$ & $(0.072)$ & $(0.062)$ & $(0.064)$ & $(0.070)$ & $(0.045)$ \\
Digitalization & $0.434^{* * *}$ & $0.524^{* * *}$ & $0.420^{* * *}$ & $0.450^{* * *}$ & $0.361^{* * *}$ & $0.398^{* * *}$ \\
& $(0.101)$ & $(0.083)$ & $(0.062)$ & $(0.096)$ & $(0.108)$ & $(0.057)$ \\
Governance & $32.503^{* * *}$ & $17.621^{* *}$ & $4.157^{* *}$ & $11.095^{* *}$ & $23.502^{* * * *}$ & $8.182^{* * *}$ \\
& $(10.688)$ & $(7.291)$ & $(1.695)$ & $(4.985)$ & $(7.308)$ & $(2.397)$ \\
Digitalization*Governance & $-0.399^{* * *}$ & $-0.285^{* *}$ & -0.025 & $-0.136^{* *}$ & $-0.313^{* * *}$ & $-0.093^{* *}$ \\
& $(0.173)$ & $(0.113)$ & $(0.028)$ & $(0.062)$ & $(0.107)$ & $(0.043)$ \\
Labor force & -0.112 & 0.314 & $1.076^{* *}$ & 0.681 & 0.515 & 0.672 \\
& $(0.000)$ & $(0.717)$ & $(0.526)$ & $(0.472)$ & $(0.795)$ & $(0.437)$ \\
Trade openness & $0.237^{* * *}$ & $0.234^{* * *}$ & $0.287^{* * *}$ & $0.256^{* * *}$ & $0.231^{* * *}$ & $0.268^{* * *}$ \\
& $(0.057)$ & $(0.072)$ & $(0.038)$ & $(0.053)$ & $(0.068)$ & $(0.049)$ \\
Inflation & 0.156 & $0.260^{* *}$ & 0.047 & 0.090 & $0.244^{* *}$ & 0.001 \\
& $(0.107)$ & $(0.128)$ & $(0.045)$ & $(0.082)$ & $(0.113)$ & $(0.049)$ \\
Infrastructure & -0.071 & -0.045 & 0.011 & -0.065 & -0.044 & -0.014 \\
& $(0.050)$ & $(0.065)$ & $(0.010)$ & $(0.051)$ & $(0.047)$ & $(0.028)$ \\
\hline Instrument & 21 & 22 & 24 & 22 & 22 & 26 \\
\hline Country/Observation & $35 / 420$ & $35 / 455$ & $35 / 420$ & $35 / 350$ & $35 / 455$ & $35 / 349$ \\
\hline AR(2) test & 0.130 & 0.508 & 0.259 & 0.281 & 0.668 & 0.133 \\
\hline Sargan test & 0.650 & 0.537 & 0.121 & 0.151 & 0.424 & 0.111 \\
\hline Hansen test & 0.463 & 0.295 & 0.354 & 0.34 & 0.202 & 0.385 \\
\hline Note: ${ }^{* * *}{ }^{* *}$ and ${ }^{*}$ denote significance at 1 percent, 5 percent and 10 & percent levels respectively
\end{tabular}

\subsection{Robustness check}

The study uses the one-step D-GMM estimator and the FE-IV estimator to check the robustness of the two-step D-GMM estimates. Digitalization is also detected to be endogenous in the estimation procedure by the one-step D-GMM estimator in Table no. 2. In line with the two-step D-GMM estimator, the results show that digitalization and governance foster economic growth while their interaction impedes it. Furthermore, trade openness also stimulates economic growth. Similarly, the results by the FE-IV estimator in Table no. 3 note digitalization, governance, and trade openness boost economic growth. 
Table no. 2 - Digitalization, governance, and economic growth: one-step D-GMM estimates, 2006 - 2019

\begin{tabular}{|c|c|c|c|c|c|c|}
\hline Variables & GOV1 & GOV2 & GOV3 & GOV4 & GOV5 & GOV6 \\
\hline Economic growth $(-1)$ & $\begin{array}{c}0.231^{* * * *} \\
(0.087)\end{array}$ & $\begin{array}{c}0.249^{* * * *} \\
(0.080)\end{array}$ & $\begin{array}{c}0.355^{* * * *} \\
(0.057)\end{array}$ & $\begin{array}{c}0.316^{* * * *} \\
(0.066)\end{array}$ & $\begin{array}{c}0.274^{* * * *} \\
(0.077)\end{array}$ & $\begin{array}{c}0.349^{* * * *} \\
(0.056)\end{array}$ \\
\hline Digitalization & $\begin{array}{c}0.319^{\text {**** }} \\
(0.081)\end{array}$ & $\begin{array}{c}0.347^{* * * *} \\
(0.066)\end{array}$ & $\begin{array}{c}0.385^{* * *} \\
(0.057)\end{array}$ & $\begin{array}{c}0.367^{* * * *} \\
(0.061)\end{array}$ & $\begin{array}{c}0.283^{* * * *} \\
(0.076)\end{array}$ & $\begin{array}{c}0.403^{* * * *} \\
(0.059)\end{array}$ \\
\hline Governance & $\begin{array}{c}36.647^{\text {***** }} \\
(13.797)\end{array}$ & $\begin{array}{c}26.980^{* * * * *} \\
(9.148)\end{array}$ & $\begin{array}{c}4.904^{* * * *} \\
(1.855)\end{array}$ & $\begin{array}{c}23.386^{* * * *} \\
(8.833)\end{array}$ & $\begin{array}{c}24.79^{* * * *} \\
(9.791)\end{array}$ & $\begin{array}{c}11.042^{* * * *} \\
(4.418)\end{array}$ \\
\hline Digitalization*Governance & $\begin{array}{c}-0.482^{* * *} \\
(0.206)\end{array}$ & $\begin{array}{c}-0.432^{* * * *} \\
(0.153)\end{array}$ & $\begin{array}{l}-0.044 \\
(0.037)\end{array}$ & $\begin{array}{c}-0.283^{* *} \\
(0.130)\end{array}$ & $\begin{array}{c}-0.295^{* *} \\
(0.143)\end{array}$ & $\begin{array}{l}-0.077^{*} \\
(0.045)\end{array}$ \\
\hline Labor force & $\begin{array}{c}0.745 \\
(0.770)\end{array}$ & $\begin{array}{c}1.281 \\
(0.821)\end{array}$ & $\begin{array}{l}1.071^{*} \\
(0.637)\end{array}$ & $\begin{array}{l}1.623^{* * *} \\
(0.784)\end{array}$ & $\begin{array}{c}1.342^{*} \\
(0.768)\end{array}$ & $\begin{array}{c}0.762 \\
(0.608)\end{array}$ \\
\hline Trade openness & $\begin{array}{l}0.177^{* * *} \\
(0.087)\end{array}$ & $\begin{array}{c}0.226^{* * * *} \\
(0.078)\end{array}$ & $\begin{array}{c}0.293^{* * * *} \\
(0.060)\end{array}$ & $\begin{array}{l}0.248^{* * * *} \\
(0.070)\end{array}$ & $\begin{array}{c}0.258^{* * * *} \\
(0.072)\end{array}$ & $\begin{array}{l}0.307^{* * * *} \\
(0.058)\end{array}$ \\
\hline Inflation & $\begin{array}{c}0.274 \\
(0.188)\end{array}$ & $\begin{array}{c}0.208 \\
(0.176)\end{array}$ & $\begin{array}{c}0.023 \\
(0.132)\end{array}$ & $\begin{array}{c}0.127 \\
(0.153)\end{array}$ & $\begin{array}{c}0.205 \\
(0.170)\end{array}$ & $\begin{array}{l}-0.015 \\
(0.126)\end{array}$ \\
\hline Infrastructure & $\begin{array}{l}-0.030 \\
(0.046)\end{array}$ & $\begin{array}{l}-0.075 \\
(0.051)\end{array}$ & $\begin{array}{c}0.016 \\
(0.016)\end{array}$ & $\begin{array}{l}-0.012 \\
(0.043)\end{array}$ & $\begin{array}{c}-0.046 \\
(0.049)\end{array}$ & $\begin{array}{c}0.005 \\
(0.014)\end{array}$ \\
\hline Instrument & 22 & 22 & 24 & 24 & 22 & 26 \\
\hline Country/Observation & $35 / 420$ & $35 / 455$ & $35 / 420$ & $35 / 350$ & $35 / 455$ & $35 / 349$ \\
\hline $\mathrm{AR}(2)$ test & 0.194 & 0.266 & 0.195 & 0.293 & 0.833 & 0.107 \\
\hline Sargan test & 0.514 & 0.537 & 0.121 & 0.137 & 0.424 & 0.151 \\
\hline
\end{tabular}

Note: ${ }^{* * *},{ }^{* *}$ and ${ }^{*}$ denote significance at 1 percent, 5 percent and 10 percent levels respectively

Table no. 3 - Digitalization, governance, and economic growth: FE-IV estimates, 2006 - 2019

Dependent variable: Economic growth (GDP per capita)

\begin{tabular}{lcccccc}
\hline Variables & GOV1 & GOV2 & GOV3 & GOV4 & GOV5 & GOV6 \\
\hline Economic growth (-1) & $0.885^{* * *}$ & $0.896^{* * * *}$ & $0.893^{* * * *}$ & $0.932^{* * *}$ & $0.893^{* * * *}$ & $0.875^{* * *}$ \\
& $(0.024)$ & $(0.027)$ & $(0.020)$ & $(0.060)$ & $(0.027)$ & $(0.026)$ \\
Digitalization & $0.067^{* * *}$ & $0.073^{* * *}$ & 0.022 & 0.044 & $0.062^{* * *}$ & $0.067^{* * *}$ \\
& $(0.020)$ & $(0.021)$ & $(0.015)$ & $(0.041)$ & $(0.024)$ & $(0.021)$ \\
Governance & $2.838^{* * *}$ & 0.866 & 1.242 & 11.298 & $5.163^{*}$ & $8.065^{* *}$ \\
& $(1.337)$ & $(2.058)$ & $(0.795)$ & $(10.744)$ & $(2.983)$ & $(3.909)$ \\
Digitalization*Governance & -0.031 & -0.002 & -0.006 & -0.002 & -0.006 & -0.025 \\
& $(0.020)$ & $(0.025)$ & $(0.014)$ & $(0.052)$ & $(0.026)$ & $(0.025)$ \\
Labor force & $0.184^{* * *}$ & 0.146 & $0.158^{* *}$ & 0.183 & $0.180^{*}$ & $0.284^{* * *}$ \\
& $(0.092)$ & $(0.098)$ & $(0.084)$ & $(0.134)$ & $(0.103)$ & $(0.114)$ \\
Trade openness & $0.074^{* * *}$ & $0.075^{* * *}$ & $0.050^{* * * *}$ & $0.082^{* * *}$ & $0.075^{* * *}$ & $0.082^{* * *}$ \\
& $(0.015)$ & $(0.015)$ & $(0.013)$ & $(0.024)$ & $(0.016)$ & $(0.016)$ \\
Inflation & $-0.087^{* * * *}$ & $-0.100^{* * * *}$ & $-0.078^{* * *}$ & $-0.140^{* *}$ & $-0.100^{* * * *}$ & $-0.094^{* * *}$ \\
& $(0.031)$ & $(0.034)$ & $(0.031)$ & $(0.058)$ & $(0.035)$ & $(0.035)$ \\
Infrastructure & -0.002 & -0.013 & $-0.015^{* *}$ & -0.033 & -0.014 & $-0.022^{* *}$ \\
& $(0.008)$ & $(0.009)$ & $(0.007)$ & $(0.023)$ & $(0.009)$ & $(0.011)$ \\
\hline Sargan test & 0.110 & 0.535 & 0.103 & 0.111 & 0.576 & 0.952 \\
\hline Nat
\end{tabular}

Note: $* * *, * *$ and $*$ denote significance at 1 percent, 5 percent and 10 percent levels respectively 


\section{CONCLUSION AND POLICY IMPLICATIONS}

Motivated from the fact that governance and digitalization play an increasingly crucial role in the process of economic development and growth in developing economies and more importantly, governance significantly contributes to the digitalization - economic growth relationship, the study empirically investigates the effects of digitalization, governance, and their interaction on economic growth for a sample of 35 developing economies between 2006 and 2019 using the difference GMM Arellano-Bond estimators and the FE-IV estimator. The results show that digitalization and governance promote economic growth while their interaction impedes it. Besides, trade openness is also a positive determinant of economic growth in these countries.

The findings in this study suggest some important policy implications for governments in developing economies in the design, formulation, and implementation of policies and regulations (governance) to support the digitalization - economic growth relationship. Progress in digital technology is a globally irreversible phenomenon and significantly contributes to the process of economic development and growth in developing countries. Regulations and policies in these countries should focus on promoting digital technology by which citizens can peacefully express their views on these policies and regulations and can easily access social platforms such as Facebook, Twitter, Instagram, etc. to learn, exchange, and express opinions appropriately. Through social platforms, for example, governments can set up the appropriate channels to collect citizens' views, ideas, and initiatives to adjust and correct regulations and policies that regulate the economic activities of the country. Institutional reforms should establish the right conditions for citizens' interaction on digital platforms. The limitation of the study is that the research sample includes only 35 developing countries due to the data not being available. It should be extended to all developing countries. Future research should investigate the different roles of governance in the digitalization - economic growth relationship between developed and developing countries.

\section{Acknowledgements}

The research work is supported by University Finance Marketing (UFM).

\section{ORCID}

Nguyen Van Bon (iD https://orcid.org/0000-0002-6281-9893

\section{References}

Acemoglu, D., Johnson, S., \& Robinson, J. A. (2005). Institutions as a Fundamental Cause of Long-Run Growth In P. Aghion \& S. N. Durlauf (Eds.), Handbook of Economic Growth (Vol. 1A): North Holland.

Albiman, M. M., \& Sulong, Z. (2016). The role of ICT use to the economic growth in Sub Saharan African region (SSA). Journal of Science and Technology Policy Management, 7(3), 306-329. http://dx.doi.org/10.1108/JSTPM-06-2016-0010

Arellano, M., \& Bond, S. (1991). Some tests of specification for panel data: Monte Carlo evidence and an application to employment equations. The Review of Economic Studies, 58(2), 277-297. http://dx.doi.org/10.2307/2297968

Bakari, S., \& Tiba, S. (2020). The Impact of Internet on Economic Growth in North Africa: New Empirical and Policy Analysis. Journal of Applied Economic Sciences, 15(3), 605-616.

Barro, R., \& Sala-i-Martin, X. (1995). Economic growth. New-York: McGraw-Hill.

Baum, C. F., Schaffer, M. E., \& Stillman, S. (2003). xtivreg2: Stata module to perform extended iv/2sls, gmm and ac/hac, liml and k-class regression for panel data models. The Stata Journal, ooo, 3. 
Chiemeke, S. C., \& Imafidor, O. M. (2020). An assessment of the impact of digital technology adoption on economic growth and labour productivity in Nigeria. NETNOMICS: Economic Research and Electronic Networking, 21(1), 103-128. http://dx.doi.org/10.1007/s11066-020-09143-7

Dobrolyubova, E., Klochkova, E., \& Alexandrov, O. (2019). Digitalization and Effective Government: What Is the Cause and What Is the Effect? In B. A. Alexandrov D., Chugunov A., Kabanov Y., Koltsova O., Musabirov I. (Ed.), Digital Transformation and Global Society (Vol. 1038, pp. 55-67): Springer. http://dx.doi.org/10.1007/978-3-030-37858-5_5

Frieden, J. (2001). Inequality, causes and possible futures. International Social Science Review, 2(1), 33-40.

Habibi, F., \& Zabardast, M. A. (2020). Digitalization, education and economic growth: A comparative analysis of Middle East and OECD countries. Technology in Society, 63, 101370. http://dx.doi.org/10.1016/j.techsoc.2020.101370

Holtz-Eakin, D., Newey, W., \& Rosen, H. S. (1988). Estimating vector autoregressions with panel data. Econometrica, 56(6), 1371-1395. http://dx.doi.org/10.2307/1913103

Hope, K. R. (2009). Capacity development for good governance in developing societies: Lessons from the field. Development in Practice, 19(1), 79-86. http://dx.doi.org/10.1080/09614520802576401

Ishida, H. (2015). The effect of ICT development on economic growth and energy consumption in Japan. Telematics and Informatics, 32(1), 79-88. http://dx.doi.org/10.1016/j.tele.2014.04.003

ITU. (2018). Measuring the Information Society Report 2018. Retrieved from https://www.itu.int/en/ITUD/Statistics/Pages/publications/misr2018.aspx

Judson, R. A., \& Owen, A. L. (1999). Estimating dynamic panel data models: A guide for macroeconomists. Economics Letters, 65(1), 9-15. http://dx.doi.org/10.1016/S0165-1765(99)00130-5

Kaufmann, D., Kraay, A., \& Mastruzzi, M. (2011). The Worldwide Governance Indicators: Methodology and Analytical Issues1. Hague Journal on the Rule of Law, 3(2), 220-246. http://dx.doi.org/10.1017/S1876404511200046

Kurniawati, M. A. (2021). Analysis of the impact of information communication technology on economic growth: empirical evidence from Asian countries. Journal of Asian Business and Economic Studies, ahead-of-print(ahead-of-print). http://dx.doi.org/10.1108/JABES-07-2020-0082

Li, S., \& Filer, L. (2007). The effects of the governance environment on the choice of investment mode and the strategic implications. Journal of World Business, 42(1), 80-98. http://dx.doi.org/10.1016/j.jwb.2006.11.006

Li, Y. (2019). Influence of the Internet on the Economic Growth of the Belt and Road Region. Global

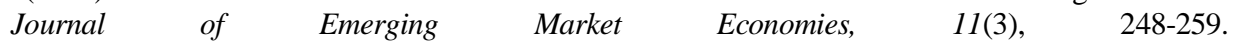
http://dx.doi.org/10.1177/0974910119887054

Myovella, G., Karacuka, M., \& Haucap, J. (2020). Digitalization and economic growth: A comparative analysis of Sub-Saharan Africa and OECD economies. Telecommunications Policy, 44(2), 101856. http://dx.doi.org/10.1016/j.telpol.2019.101856

Nair, M., Pradhan, R. P., \& Arvin, M. B. (2020). Endogenous dynamics between R\&D, ICT and economic growth: Empirical evidence from the OECD countries. Technology in Society, 62, 101315. http://dx.doi.org/10.1016/j.techsoc.2020.101315

Ndubuisi, G., Otioma, C., \& Tetteh, G. K. (2021). Digital infrastructure and employment in services: Evidence from Sub-Saharan African countries. Telecommunications Policy, 45, 102153. http://dx.doi.org/10.1016/j.telpol.2021.102153

Qu, J., Simes, R., \& O'Mahony, J. (2017). How do digital technologies drive economic growth? The Economic Record, 93, 57-69. http://dx.doi.org/10.1111/1475-4932.12340

Roodman, D. (2009). How to do xtabond2: An introduction to difference and system GMM in Stata. The Stata Journal, 9(1), 86-136. http://dx.doi.org/10.1177/1536867X0900900106

Siddiqui, A. A., \& Singh, P. (2019). ICT Penetration and Economic Growth: An Empirical Analysis of Major Trading Nations. The Indian Economic Journal, 67(3-4), 312-333. http://dx.doi.org/10.1177/0019466220951787

Solomon, E. M., \& van Klyton, A. (2020). The impact of digital technology usage on economic growth in Africa. Utilities Policy, 67, 101104. http://dx.doi.org/10.1016/j.jup.2020.101104 
UNCTAD. (2018). The digital divide is impeding development. Retrieved from https://unctad.org/news/digital-divide-impeding-development

UNCTAD. (2021). Digital Economy Report 2019 - Value creation and capture: Implications for developing countries. Retrieved from https://unctad.org/webflyer/digital-economy-report-2019

United Nations, U. N. (2000). Millennium Development Goals and Beyond 2015. Retrieved from https://www.un.org/millenniumgoals/

United Nations, U. N. (2020). Inequality - Bridging the Divide. Retrieved from https://www.un.org/en/un75/inequality-bridging-divide

Usman, A., Ozturk, I., Hassan, A., Zafar, S. M., \& Ullah, S. (2021). The effect of ICT on energy consumption and economic growth in South Asian economies: An empirical analysis. Telematics and Informatics, 58, 101537. http://dx.doi.org/10.1016/j.tele.2020.101537

$\mathrm{Vu}, \mathrm{K} . \mathrm{M}$. (2011). ICT as a source of economic growth in the information age: Empirical evidence from the 1996-2005 period. Telecommunications Policy, 35(4), 357-372. http://dx.doi.org/10.1016/j.telpol.2011.02.008

Yousefi, A. (2011). The impact of information and communication technology on economic growth: Evidence from developed and developing countries. Economics of Innovation and New Technology, 20(6), 581-596. http://dx.doi.org/10.1080/10438599.2010.544470

\section{ANNEX}

Table A - Data description

\begin{tabular}{|c|c|c|c|}
\hline Variable & Definition & \multicolumn{2}{|c|}{ Type Source } \\
\hline $\begin{array}{l}\text { Economic growth } \\
\text { (GDP) }\end{array}$ & GDP per capita (constant 2010 US\$) & $\log$ & $\begin{array}{l}\text { World } \\
\text { Bank }\end{array}$ \\
\hline $\begin{array}{l}\text { Digitalization } \\
\text { (DIG) }\end{array}$ & $\begin{array}{l}\text { Individuals using the Internet ( } \% \text { of population). Internet users are individuals } \\
\text { who have used the Internet (from any location) in the last } 3 \text { months. The Internet } \\
\text { can be used via a computer, mobile phone, personal digital assistant, games } \\
\text { machine, digital TV,... }\end{array}$ & $\%$ & $\begin{array}{l}\text { World } \\
\text { Bank }\end{array}$ \\
\hline Labor force (LAB) & Labor force participation rate, total (\% of total population ages $15-64)$ & $\%$ & $\begin{array}{l}\text { World } \\
\text { Bank }\end{array}$ \\
\hline $\begin{array}{l}\text { Trade openness } \\
(\mathrm{OPE})\end{array}$ & $\begin{array}{l}\text { Trade is the sum of exports and imports of goods and services measured as a } \\
\text { share of GDP. }\end{array}$ & $\%$ & $\begin{array}{l}\text { World } \\
\text { Bank }\end{array}$ \\
\hline Inflation (INF) & Inflation, consumer prices (annual \%) & $\%$ & $\begin{array}{l}\text { World } \\
\text { Bank }\end{array}$ \\
\hline $\begin{array}{l}\text { Infrastructure } \\
\text { (TEL) }\end{array}$ & Fixed telephone subscriptions (per 100 people) & $\log$ & $\begin{array}{l}\text { World } \\
\text { Bank }\end{array}$ \\
\hline $\begin{array}{l}\text { Regulatory Quality } \\
\text { (GOV1) }\end{array}$ & $\begin{array}{l}\text { Regulatory Quality captures perceptions of the ability of the government to } \\
\text { formulate and implement sound policies and regulations that permit and } \\
\text { promote private sector development. }\end{array}$ & & \\
\hline $\begin{array}{l}\text { Rule of Law } \\
\text { (GOV2) }\end{array}$ & $\begin{array}{l}\text { Rule of Law captures perceptions of the extent to which agents have confidence } \\
\text { in and abide by the rules of society, and in particular the quality of contract } \\
\text { enforcement, property rights, the police, and the courts, as well as the likelihood } \\
\text { of crime and violence. }\end{array}$ & & \\
\hline $\begin{array}{l}\text { Voice and } \\
\text { Accountability } \\
\text { (GOV3) }\end{array}$ & $\begin{array}{l}\text { Voice and Accountability captures perceptions of the extent to which a } \\
\text { country's citizens are able to participate in selecting their government, as well } \\
\text { as freedom of expression, freedom of association, and a free media. }\end{array}$ & level & $\begin{array}{l}\text { World } \\
\text { Bank }\end{array}$ \\
\hline $\begin{array}{l}\text { Control of } \\
\text { Corruption } \\
\text { (GOV4) }\end{array}$ & $\begin{array}{l}\text { Control of Corruption captures perceptions of the extent to which public power } \\
\text { is exercised for private gain, including both petty and grand forms of corruption, } \\
\text { as well as "capture" of the state by elites and private interests. }\end{array}$ & & \\
\hline $\begin{array}{l}\text { Government Effec- } \\
\text { tiveness (GOV5) }\end{array}$ & $\begin{array}{l}\text { Government Effectiveness captures perceptions of the quality of public } \\
\text { services, the quality of the civil service and the degree of its independence from } \\
\text { political pressures, the quality of policy formulation and implementation, and } \\
\text { the credibility of the government's commitment to such policies. }\end{array}$ & & \\
\hline
\end{tabular}




\begin{tabular}{llr}
\hline Variable & Definition & Type Source \\
\hline $\begin{array}{l}\text { Political Stability } \\
\text { (GOV6) }\end{array}$ & $\begin{array}{l}\text { Political Stability and Absence of Violence/Terrorism measures perceptions of } \\
\text { the likelihood of political instability and/or politically-motivated violence, } \\
\text { including terrorism. }\end{array}$ \\
\hline
\end{tabular}

Table B - Descriptive statistics for 35 developing countries

\begin{tabular}{lccccc}
\hline Variable & Obs. & Mean & Std. Dev. & Min & Max \\
\hline Economic growth & 490 & 6909.33 & 4203.859 & 762.520 & 17570.17 \\
Digitalization & 490 & 43.085 & 21.207 & 3.268 & 84.516 \\
Labor force & 490 & 67.519 & 8.335 & 40.14 & 83.21 \\
Trade openness & 490 & 82.855 & 39.018 & 22.10598 & 210.400 \\
Inflation & 490 & 5.537 & 5.997 & -1.544 & 59.219 \\
Infrastructure & 490 & 18.082 & 9.599 & 1.136 & 48.103 \\
\hline Regulatory quality & 490 & -0.337 & 0.541 & -1.319 & 1.582 \\
Rule of Law & 490 & -0.093 & 0.528 & -1.269 & 1.275 \\
Voice and Accountability & 490 & -0.329 & 0.759 & -2.810 & 1.072 \\
Control of Corruption & 490 & -0.033 & 0.596 & -1.622 & 1.538 \\
Government Effectiveness & 490 & -0.320 & 0.565 & -1.371 & 1.433 \\
Political Stability & 489 & -0.1382 & 0.704 & -1.753 & 1.151 \\
\hline
\end{tabular}

Table $\mathrm{C}$ - The matrix of correlation coefficients between variables

\begin{tabular}{|c|c|c|c|c|c|c|}
\hline & GDP & DIG & LAB & OPE & INF & TEL \\
\hline GDP & 1 & & & & & \\
\hline DIG & $0.600^{* * *}$ & 1 & & & & \\
\hline LAB & $0.148^{* * * *}$ & 0.068 & 1 & & & \\
\hline OPE & $-0.128^{* * *}$ & $0.087^{* *}$ & $0.111^{* * *}$ & 1 & & \\
\hline INF & $-0.111^{* *}$ & $-0.159^{* * *}$ & 0.009 & -0.000 & 1 & \\
\hline TEL & $0.605^{* * *}$ & $0.331^{* * *}$ & 0.048 & $0.115^{* * *}$ & $0.124^{* * *}$ & 1 \\
\hline
\end{tabular}

Note: $* * *, * *$ and $*$ denote significance at 1 percent, 5 percent and 10 percent levels respectively

Table D - The matrix of correlation coefficients between dimensions of governance

\begin{tabular}{|c|c|c|c|c|c|c|}
\hline & GOV1 & GOV2 & GOV3 & GOV4 & GOV5 & GOV6 \\
\hline GOV1 & 1 & & & & & \\
\hline GOV2 & $0.793^{* * *}$ & 1 & & & & \\
\hline GOV3 & $0.438^{* * * *}$ & $0.435^{\text {**** }}$ & 1 & & & \\
\hline GOV4 & $0.740^{\text {**** }}$ & $0.790^{\text {**** }}$ & $0.364^{* * *}$ & 1 & & \\
\hline GOV5 & $0.879^{* * * *}$ & $0.859^{\text {**** }}$ & $0.483^{* * *}$ & $0.846^{* * *}$ & 1 & \\
\hline GOV6 & $0.575^{\text {**** }}$ & $0.427^{* * *}$ & $0.424^{* * *}$ & $0.587^{* * *}$ & $0.569^{* * *}$ & 1 \\
\hline
\end{tabular}

Note: $* * *, * *$ and $*$ denote significance at 1 percent, 5 percent and 10 percent levels respectively

\section{Notes}

${ }^{1}$ Argentina, Armenia, Belarus, Bolivia, Brazil, Bulgaria, Chile, China, Colombia, Costa Rica, Croatia, Dominican Republic, Ecuador, El Salvador, Georgia, Honduras, Hungary, Indonesia, Kazakhstan, Kyrgyz Republic, Malaysia, Mexico, Moldova, Pakistan, Panama, Paraguay, Peru, Poland, Romania, Russian Federation, Thailand, Turkey, Ukraine, Vietnam, and West Bank and Gaza.

\section{Copyright}

This article is an open access article distributed under the terms and conditions of the Creative Commons Attribution-NonCommercial-NoDerivatives 4.0 International License. 